\title{
PENERAPAN PEMBELAJARAN KOOPERATIF TIPE TSOS (THREE STAY ONE STRAY) UNTUK MENINGKATKAN KETERAMPILAN SOSIAL SISWA KELAS IV PADA MATA PELAJARAN IPA DI SDN KANIGORO 03 KOTA MADIUN
}

\author{
Selly Nurina Suraya *
}

\begin{abstract}
The objective of this research is to improve the fourth graders' social skills in the subject of natural science through applying type of TSOS at the elementary school of SD Kanigooro 03 Madiun. The mothod adopted is qualitative while the design is classroom action research. The research took place at SD 03 Kanigoro 04 for 4 months, i.e. February through Mei 2011. As many as 31 students involved as the subject of this research. Data were collected through observation. It was applied to observe their social skills (affective domain) during the teaching-learning process which covered the skills to share, to participate, and to communicate. An observation sheet was the instrument to collect data during the observation which, then, descriptively analyzed. Results in the first cycle showed their average scores came out of a single social skill. The average of every aspect, respectively,: the skill to share 63.74; that to participate 64.58; and that on communication 59.77. Results in the second cycle indicated a significant increase. They could share, participate and communicate better than before. Their average scores were: 84.67 for the skill to share; 87.09 for that to participate; and 84.67 for that for communication. A conclusion drawn is that the cooperative learning type of TSOS can improve the fourth graders' social skills of SD Kanigoro 03 Madiun. Their average skill to share improved from 63.74 in the first cycle to 84.67 in the second cycle. That on the participation was from 64.58 to 87.09. Last of all, that on communication was from 59.77 to 84.67.
\end{abstract}

Keywords: Cooperative Learning Type TSOS, Social Skills, Natural Science

\begin{abstract}
Abstrak
Tujuan penelitian ini adalah untuk meningkatkan keterampilan sosial siswa kelas IV pada mata pelajaran IPA melalui penerapan pembelajaran kooperatif tipe TSOS di SDN Kanigoro 3 Madiun. Metode penelitian yang digunakan adalah penelitian kualitatif dengan rancangan penelitian tindakan kelas. Penelitian ini dilaksanakan di SDN Kanigoro 3 Madiun selama 4 bulan mulai
\end{abstract}

* Selly Nurina Suraya adalah Dosen Prodi PGSD IKIP PGRI Madiun 
bulan Februari sampai dengan Mei 2011. Subjek penelitiannya siswa kelas IV sejumlah 31 orang. Teknik pengumpulan data menggunakan teknik observasi. Teknik observasi dilakukan untuk mengamati keterampilan sosial (sikap afektif siswa) dalam proses pembelajaran, meliputi keterampilan berbagi, partisipasi dan komunikasi. Data diperoleh dari observasi proses pembelajaran yang diambil menggunakan lembar observasi penilaian afektif (keterampilan sosial), kemudian dianalisis secara deskriptif. Hasil penelitian untuk melatihkan keterampilan sosial siswa pada siklus I menunjukkan bahwa rata-rata setiap siswa hanya menunjukkan 1 macam keterampilan sosial. Nilai rata-rata setiap aspeknya, yaitu keterampilan berbagi 63,74; keterampilan partisipasi 64,58; keterampilan komunikasi 59,77. Mengalami peningkatan pada siklus II, dimana siswa dapat melakukan komunikasi, berbagi dan berpartisipasi yang lebih baik lagi dengan temannya dalam diskusi. Nilai rata-rata tiap aspeknya, yaitu keterampilan berbagi 84,67; keterampilan partisipasi 87,09; dan keterampilan komunikasi 84,67. Berdasarkan hasil penelitian dan analisis data yang telah dilakukan disimpulkan bahwa melalui penerapan pembelajaran kooperatif tipe TSOS dapat meningkatkan keterampilan sosial siswa kelas IV pada mata pelajaran IPA di SDN Kanigoro 3 Madiun yang ditunjukkan dengan data peningkatan antara lain: keterampilan berbagi dari siklus I rata-rata 63,74 ke siklus II rata-rata 84,67 keterampilan partisipasi dari siklus I rata-rata 64,58 ke siklus II rata-rata 87,09 dan keterampilan komunikasi dari siklus I rata-rata 59,77 ke siklus II rata-rata 84,67 .

\section{Kata Kunci: Pembelajaran Kooperatif Tipe TSOS, Keterampilan Sosial, IPA}

\section{A. PENDAHULUAN}

Proses pembelajaran di kelas dalam Kurikulum Tingkat Satuan Pendidikan (KTSP) harus memperhatikan aspek kognitif, afektif, dan psikomotorik. Namun pada pelaksanaannya belum sepenuhnya optimal karena masih sering menggunakan metode ceramah pada saat proses pelaksanaan pembelajaran. Pada pembelajaran tradisional yang cukup banyak dipraktekkan dalam pembelajaran di kelas, guru biasanya menjadi pusat kegiatan belajar, dimana guru menyampaikan berbagai pengetahuan yang dianggapnya diperlukan oleh siswa, sementara siswa diarahkan untuk memperhatikan penjelasan guru. Komunikasi yang terjadi didominasi oleh komunikasi satu arah, kecuali pada saat tertentu guru mungkin mempersilahkan para siswa untuk mengajukan pertanyaan bila ada hal-hal yang belum dimengerti.

Pada dasarnya tidak semua siswa bermasalah pada saat guru menerangkan pelajaran dengan menggunakan metode ceramah. Namun terkesan hanya siswa yang berada di bangku paling depan saja yang memperhatikan pelajaran dengan baik sehingga kelas terkesan di dominasi oleh siswa-siswa yang mempunyai 
kemampuan diatas rata-rata dan siswa cenderung bersikap individual. Pada proses pembelajaran dengan metode ceramah siswa biasanya kurang aktif dalam pelaksanaan proses belajar sehingga kelas terkesan kurang terkoordinir dengan baik. Melalui metode ceramah ini siswa terkesan bosan, ngantuk, dan tidak memperhatikan penjelasan yang disampaikan guru. Siswa tidak aktif bertanya ataupun mengemukakan pendapatnya sehingga informasi hanya berjalan satu arah yaitu dari guru kepada siswa.

Pada saat peneliti melakukan observasi di SDN Kanigoro 3 mengenai pelaksanaan kegiatan pembelajaran mata pelajaran IPA, pada umumnya belum sepenuhnya optimal. Karena materi IPA yang diajarkan hanya menekankan pada aspek kognitif saja, sehingga siswa kurang suka dengan pelajaran IPA karena banyak materi menghafal. Selain itu siswa masih menunjukkan sikap egois, individualis, dan hanya mau berkumpul dengan kelompoknya saja.

Pada saat peneliti melakukan observasi mengenai nilai Kriteria Ketuntasan Belajar Minimal (KKM) individu yang harus dipenuhi oleh siswa, diperoleh informasi bahwa siswa harus mampu memperoleh nilai $\geq 70$ yang ditentukan sekolah sebagai standar ketuntasan belajar minimal di SDN Kanigoro 3 Madiun. Untuk KKM klasikal, siswa satu kelas dikatakan tuntas belajar jika terdapat $85 \%$ siswa yang memperoleh nilai $\geq 70$. Peneliti memperoleh data nilai siswa yang telah tuntas dan yang belum tuntas dalam belajar. Terdapat 4 siswa $(12,9 \%)$ yang telah tuntas belajar dan 27 siswa $(87,1 \%)$ belum tuntas belajar sehingga harus mengikuti pelajaran remidi agar dapat mencapai standar ketuntasan belajar yang telah ditentukan. Hasil tes yang peneliti peroleh tersebut adalah dari mata pelajaran IPA pada siswa kelas IV semester gasal tahun ajaran 2010/2011. Sebagai akibatnya, pada saat pembelajaran IPA yang sedikit rumit, sikap antar siswa justru tidak memperlihatkan aspek keterampilan sosial. Siswa yang lebih paham cenderung acuh terhadap temannya yang kurang paham. Kondisi yang lebih ironis muncul saat siswa yang lebih paham mengejek siswa yang kurang paham. Hal ini menjadikan suasana kelas tidak kondusif dan kerjasama tidak tercipta sehingga prestasi belajar dan keterampilan siswa kurang memuaskan.

Dari gambaran permasalahan di atas dibutuhkan suatu proses pembelajaran yang mengacu pada penguasaan ranah kognitif, psikomotorik dan utamanya afektif yang ditekankan pada penguasaan social skill atau keterampilan sosial. Melalui pembelajaran kooperatif, siswa yang kurang pandai atau mengalami hambatan dalam pembelajaran, akan memperoleh bantuan dari siswa lain dalam kelompoknya, sehingga masalah yang dihadapi akan dapat diselesaikan dengan bantuan teman dalam kelompok. Sementara itu siswa yang pandai, akan membantu siswa lain dengan cara mengajarkan beberapa hal berkaitan dengan materi pelajaran yang sedang dibahas, sehingga dengan sendirinya siswa pandai tersebut akan mencurahkan kemampuan berpikirnya lebih banyak, dan pada akhirnya penguasaan terhadap materi pelajaran semakin besar.

Keterampilan sosial yang perlu dikuasai dan dikembangkan oleh setiap siswa tentu sangat beragam dan kompleks. Namun demikian untuk kepentingan pembelajaran di kelas dan dalam kaitannya dengan terlaksananya pembelajaran yang produktif untuk mencapai tujuan, Arends (1997:136) mengelompokkan keterampilan sosial dalam pembelajaran kooperatif terdiri dari: (1) keterampilan 
berbagi; (2) keterampilan partisipasi; dan (3) keterampilan komunikasi. Pengelompokkan keterampilan sosial yang dilakukan oleh Arends ini menjadi dasar dalam penelitian ini untuk diperhatikan dan dianalisa lebih jauh. Peneliti memilih salah satu tipe dari pembelajaran kooperatif yaitu TSOS (Three Stay One Stray). Penerapan pembelajaran kooperatif tipe TSOS merujuk pada konsep Kagan untuk melibatkan lebih banyak siswa dalam menelaah materi yang tercakup dalam suatu pelajaran, dan memungkinkan guru mengecek pemahaman para siswa mengenai isi pelajaran tersebut melalui respon yang diberikan baik oleh siswa pandai, sedang, maupun kurang (Kagan, 2009). Dengan demikian, guru dapat memperoleh hasil pengukuran otentik (authentic assessment) penguasaan para siswa.

Inti dari pembelajaran kooperatif tipe TSOS adalah: (1) para siswa bekerja dalam kelompoknya memecahkan masalah; (2) salah satu anggota kelompok bertamu ke kelompok lain untuk membandingkan hasil jawaban kelompoknya dengan jawaban kelompok lain; (3) siswa yang bertamu kembali ke kelompoknya semula untuk mendiskusikan hasil bertamu yang dilakukan; dan (4) bila terjadi ketidak sesuaian jawaban, para siswa dalam kelompok dapat melakukan kembali pemecahan masalah, merubah jawaban kelompoknya, atau bertahan dengan jawaban kelompoknya (Maitland, dkk. 2009). Tujuan penelitian ini adalah untuk meningkatkan keterampilan sosial siswa kelas IV pada mata pelajaran IPA melalui penerapan pembelajaran kooperatif tipe TSOS di SDN Kanigoro 3 Madiun.

\section{B. KAJIAN PUSTAKA}

Pembelajaran kooperatif adalah salah satu bentuk pembelajaran berdasarkan paham konstruktivis. Pembelajaran kooperatif merupakan strategi belajar dengan sejumlah siswa sebagai anggota kelompok kecil yang tingkat kemampuannya berbeda. Dalam menyelesaikan tugas kelompoknya, setiap siswa anggota kelompok harus saling bekerja sama dan saling membantu untuk memahami materi pelajaran. Dalam pembelajaran kooperatif, belajar dikatakan belum selesai jika salah satu teman dalam kelompok belum menguasai bahan pelajaran. Pembelajaran kooperatif turut menambah unsur-unsur interaksi sosial pada pembelajaran sains. Di dalam kooperatif siswa belajar bersama dalam kelompok-kelompok kecil yang saling membantu satu sama lain. Kelas disusun dalam kelompok yang terdiri dari 4 atau 6 orang siswa, dengan kemampuan yang heterogen. Maksud kelompok heterogen adalah terdiri dari campuran kemampuan siswa, jenis kelamin, dan suku. Hal ini bermanfaat untuk melatih siswa menerima perbedaan dan bekerja dengan teman yang berbeda latar belakangnya. Pada pembelajaran kooperatif diajarkan keterampilan-keterampilan khusus agar dapat bekerja sama dengan baik di dalam kelompoknya, seperti menjadi pendengar yang baik, siswa diberi lembar kegiatan yang berisi pertanyaan atau tugas yang direncanakan untuk diajarkan. Selama kerja kelompok, tugas anggota kelompok adalah mencapai ketuntasan (Slavin, 1995).

Beberapa ciri dari pembelajaran kooperatif adalah; (a) setiap siswa memiliki peran, (b) terjadi hubungan interaksi langsung di antara siswa, (c) setiap anggota kelompok bertanggung jawab atas belajarnya dan juga teman-teman 
sekelompoknya, (d) guru membantu mengembangkan keterampilan-keterampilan interpersonal kelompok, (e) guru hanya berinteraksi dengan kelompok saat diperlukan. Tiga konsep sentral yang menjadi karakteristik pembelajaran kooperatif sebagaimana dikemukakan oleh Slavin (1995), yaitu penghargaan kelompok, pertanggungjawaban individu dalam kelompok, dan kesempatan yang sama untuk berhasil.

Para peneliti telah menemukan bahwa pembelajaran kooperatif dapat menjadi strategi yang efektif untuk meningkatkan prestasi, terutama jika dua syarat berikut ini dipenuhi, yaitu: (1) disediakan penghargaan kepada kelompok, sehingga anggota kelompok itu dapat memahami bahwa membantu orang lain adalah demi kepentingan diri mereka juga; dan (2) individu dimintai pertanggung jawaban, untuk mengevaluasi kontribusi individual, misalnya dengan menggunakan tes (Santrock, 2007:397). Evaluasi dimaksudkan untuk memberi motivasi kepada seluruh siswa agar berusaha dengan sungguh-sungguh dalam belajarnya dan berpartisipasi aktif memberi kontribusi pada semua proses pembahasan materi pelajaran dalam kelompok. Evaluasi juga dimaksudkan untuk menghindari adanya murid yang bermalas-malasan, atau merasa diabaikan karena merasa dirinya tidak banyak memberi kontribusi. Menurut Miller dan Peterson (1992) tujuan kelompok diperlukan untuk memotivasi siswa agar saling membantu dalam belajar dengan memberi bantuan bagi kesuksesan satu sama lain. Tanggung jawab individu, berperan untuk mencegah kemungkinan bahwa satu atau dua anggota kelompok akan melakukan semua pekerjaan. Sehingga jika kesuksesan kelompok bergantung pada belajar individu tiap anggota kelompok, maka diharapkan semua anggota kelompok lebih termotivasi untuk terlibat dalam menguasai materi yang dipelajari.

Arends (1997:111) mengemukakan bahwa model pembelajaran kooperatif dikembangkan untuk memperoleh sekurang-kurangnya tiga tujuan pembelajaran yang penting yakni: (1) prestasi akademik; (2) penerimaan terhadap perbedaan; dan (3) pengembangan keterampilan sosial. Pembelajaran kooperatif tipe Three Stay One Stray (TSOS) atau dapat diterjemahkan sebagai tipe tiga tinggal satu bertamu, merupakan salah satu bentuk pembelajaran kooperatif dengan pendekatan struktural, yang menekankan pada penggunaan desain struktur tertentu untuk mempengaruhi pola-pola interaksi siswa. Struktur tersebut dikembangkan oleh Kagan yang mengarahkan siswa bekerja secara independen dalam kelompokkelompok kecil yang dicirikan oleh pemberian penghargaan kelompok daripada individu (Arends, 1997:121). Menurut Arends (1997:124) salah satu keuntungan dari pendekatan struktural ini adalah disamping mengarahkan pada tujuan akademik, juga pada tujuan sosial yang terdiri dari terbangunnya kerja sama kelompok dan keterampilan sosial.

Inti dari pembelajaran kooperatif tipe TSOS adalah: (1) para siswa bekerja dalam kelompoknya memecahkan masalah, (2) salah satu anggota kelompok bertamu ke kelompok lain untuk membandingkan hasil jawaban kelompoknya dengan jawaban kelompok lain, (3) siswa yang bertamu kembali ke kelompoknya semula untuk mendiskusikan hasil bertamu yang dilakukan, (4) Bila terjadi ketidak sesuaian jawaban, para siswa dalam kelompok dapat melakukan kembali pemecahan masalah, merubah jawaban kelompoknya, atau bertahan dengan 
jawaban kelompoknya (Maitland, dkk. 2009). Keterampilan sosial sebagai kemampuan individu dalam berinteraksi sosial dengan masyarakat di lingkungannya dalam rangka memenuhi kebutuhannya untuk dapat diterima oleh teman sebaya, baik sejenis kelamin atau lawan jenis agar ia memperoleh rasa dibutuhkan dan rasa berharga. Keterampilan sosial dapat membawa anak untuk lebih berani menyatakan diri, mengungkapkan setiap perasaan atau permasalahan yang dihadapi dan sekaligus menemukan penyelesaian yang adaptif, sehingga mereka tidak mencari pelarian ke hal-hal lain yang justru dapat merugikan diri sendiri dan orang lain.

Bila dihubungkan dengan penerapan model pembelajaran kooperatif tipe TSOS, maka ketiga keterampilan sosial yakni keterampilan berbagi, keterampilan partisipasi dan keterampilan komunikasi dengan sendirinya akan terpacu untuk dilaksanakan oleh setiap siswa dalam semua kegiatan kelompoknya. Pelaksanaan ketiga keterampilan sosial tersebut terjadi baik ketika diskusi pada kelompok asal, ketika diskusi pada kelompok baru pada saat melakukan kegiatan bertamu, ketika diskusi kembali pada kelompok asal untuk merefleksi jawaban kelompok, maupun ketika mengambil kesimpulan dan presentasi hasil kerja kelompok. Dengan semakin seringnya para siswa melakukan tiga keterampilan sosial tersebut dalam kegiatan belajar, maka diharapkan akan terjadi peningkatan keterampilan sosial yang dimilikinya.

Langkah pembelajaran kooperatif tipe TSOS dapat dijabarkan dalam bentuk yang lebih operasional, yaitu: (1) guru mengelompokkan siswa kedalam kelompok terdiri dari 4 orang dengan tingkat kemampuan dan latar belakang berbeda; (2) guru memberikan masalah kepada para siswa untuk dipecahkan melalui diskusi dalam kelompoknya; (3) setelah diskusi kelompok selesai dilakukan, dan setiap anggota kelompok telah menunjukkan bahwa mereka mampu melaporkan hasil kerja kelompok, guru menyuruh berdiri satu orang anggota pada tiap-tiap kelompok untuk bertamu ke kelompok lain; (4) satu orang anggota dari tiap-tiap kelompok yang bertamu, selanjutnya bergabung dengan kelompok baru untuk membandingkan jawaban kelompoknya dengan jawaban kelompok yang baru. Pada proses ini, anggota yang menjadi tamu akan memberi penjelasan tentang hasil kerja kelompoknya dan menerima penjelasan tentang hasil kerja kelompok yang dikunjunginya; (5) dengan petunjuk guru, kemudian siswa kembali ke kelompoknya semula untuk mendiskusikan jawaban yang diperoleh dari kelompok lain; (6) bila ada ketidaksesuaian jawaban, maka kelompok dapat mengerjakan kembali pemecahan masalah, atau merubah jawabannya semula, atau bertahan dengan jawaban yang mereka telah peroleh sebelumnya; (7) rotasi kedua dapat dilakukan (bila diperlukan) khususnya bila masalah yang dipecahkan memerlukan berpikir divergen, atau solusi divergen; dan (8) guru memanggil juru bicara kelompok untuk mengemukakan jawabannya ke seluruh kelas.

\section{METODE PENELITIAN}

Penelitian ini dilaksanakan di SDN Kanigoro 3 Madiun selama 4 bulan mulai bulan Februari sampai dengan Mei 2011. Subjek penelitiannya siswa kelas IV sejumlah 31 orang. Adapun alur penelitian tindakan kelas menurut model 
Kemmis dan McTaggart pelaksanaan penelitian tindakan mencakup empat langkah, yaitu: merumuskan masalah dan merencanakan tindakan, melaksanakan tindakan dan pengamatan / monitoring, refleksi hasil pengamatan, serta perubahan / revisi perencanaan untuk pengembangan selanjutnya (Ghony, 2008: 15). Kemmis dan McTaggart menggunakan empat komponen penelitian tindakan (perencanaan, tindakan, observasi, dan refleksi) dalam suatu sistem spiral yang saling terkait. Penelitian ini dilakukan dua siklus. Setiap siklusnya terdiri dari satu pertemuan (2 x 35 menit). Materi pelajaran yang diajarkan menggunakan pembelajaran kooperatif pada penelitian ini adalah IPA dengan pokok bahasan sumber daya alam.

Teknik pengumpulan datanya adalah dengan teknik observasi. Teknik observasi dilakukan untuk mengamati keterampilan sosial (sikap afektif siswa) dalam proses pembelajaran, meliputi keterampilan berbagi, partisipasi dan komunikasi. Data diperoleh dari observasi proses pembelajaran yang diambil menggunakan lembar observasi penilaian afektif (keterampilan sosial), kemudian dianalisis secara deskriptif.

\section{HASIL PENELITIAN DAN PEMBAHASAN}

Penelitian ini dilakukan dalam dua siklus untuk melihat peningkatan aspek keterampilan sosial siswa pada mata pelajaran IPA pokok bahasan sumber daya alam. Setiap siklusnya terdiri dari 1 pertemuan $(2$ x 35 menit). Siklus pertama dilakukan pada tanggal 14 April 2011. Siklus kedua dilakukan pada tanggal 20 April 2011. Penilaian keterampilan sosial siswa diperoleh melalui observasi. Hasil observasi keterampilan sosial siswa dalam kelompoknya ditunjukkan dengan skor 1, 2, 3, dan 4. Ketika dikonversikan sebagai nilai skala 0 s.d. 100; maka skor 1 sama dengan 25; 2 sama dengan 50; 3 sama dengan 75; dan skor 4 sama dengan 100 .

Pada penelitian ini terdapat 9 poin keterampilan sosial yang dilatihkan kepada siswa dalam pembelajaran. Ditinjau dari jenis keterampilan sosial yang dilakukan menurut pengelompokan Arends (1997) keterampilan sosial yang dilatihkan terdiri dari: (1) keterampilan berbagi, meliputi keterampilan menggunakan kesepakatan, menghargai kontribusi orang lain, dan keterampilan bertanya; (2) keterampilan partisipasi, meliputi selalu berada dalam kelompok, menghormati perbedaan pendapat, dan mendengar dengan aktif; dan (3) keterampilan komunikasi, meliputi mengungkapkan ketidaksetujuan dengan cara yang sopan, mengulang informasi dengan kalimat sendiri, dan memeriksa kebenaran informasi yang diterima. Berikut hasil analisis observasi keterampilan sosial siswa pada siklus I dan siklus II.

\section{Tabel 1 Hasil Observasi Penilaian Keterampilan Sosial Siswa Siklus I}

\begin{tabular}{clcccc}
\hline \multirow{2}{*}{ No. } & Nama Siswa & \multicolumn{3}{c}{$\begin{array}{c}\text { Nilai tiap aspek yang } \\
\text { diamati }\end{array}$} & \multirow{2}{*}{$\begin{array}{c}\text { Rata-Rata } \\
\text { Nilai }\end{array}$} \\
\cline { 3 - 5 } & & $\mathbf{1}$ & $\mathbf{2}$ & $\mathbf{3}$ & \\
\hline 1 & Armando Ricantona & 75 & 75 & 50 & 66.7 \\
2 & Arga Anggar & 50 & 50 & 50 & 50.0 \\
3 & Ayu Kumalasari & 75 & 75 & 50 & 66.7 \\
4 & Ade Irma Surya & 50 & 50 & 50 & 50.0
\end{tabular}




\begin{tabular}{|c|c|c|c|c|c|}
\hline \multirow[t]{2}{*}{ No. } & \multirow[t]{2}{*}{ Nama Siswa } & \multicolumn{3}{|c|}{$\begin{array}{c}\text { Nilai tiap aspek yang } \\
\text { diamati }\end{array}$} & \multirow{2}{*}{$\begin{array}{c}\text { Rata-Rata } \\
\text { Nilai }\end{array}$} \\
\hline & & 1 & 2 & 3 & \\
\hline 5 & Arung Ega R & 50 & 25 & 50 & 41.7 \\
\hline 6 & Dimas Firmansyah & 75 & 75 & 75 & 75.0 \\
\hline 7 & Devi Yunita Sari & 75 & 75 & 75 & 75.0 \\
\hline 8 & Ester Danisa & 75 & 75 & 75 & 75.0 \\
\hline 9 & Ferian Dandi A.S & 75 & 75 & 75 & 75.0 \\
\hline 10 & Hawa Mayra JK & 75 & 75 & 75 & 75.0 \\
\hline 11 & Hifni Khoirul Rosyid & 50 & 50 & 50 & 50.0 \\
\hline 12 & Ibnu Setiawan & 75 & 75 & 75 & 75.0 \\
\hline 13 & Ika Puji Lestari & 50 & 50 & 50 & 50.0 \\
\hline 14 & Iriana Wahyuning & 50 & 50 & 50 & 50.0 \\
\hline 15 & Irvan Putra $\mathrm{M}$ & 50 & 50 & 50 & 50.0 \\
\hline 16 & Lucya Nurani DP & 75 & 50 & 75 & 66.7 \\
\hline 17 & Mario Suryoko & 50 & 50 & 50 & 50.0 \\
\hline 18 & Novi Nurhandayani & 75 & 75 & 50 & 66.7 \\
\hline 19 & Putri lioni M & 75 & 75 & 75 & 75.0 \\
\hline 20 & Rizal Afridi & 75 & 75 & 50 & 66.7 \\
\hline 21 & Rukmania Nur A & 75 & 50 & 50 & 58.3 \\
\hline 22 & Tania Putri P & 75 & 75 & 75 & 75.0 \\
\hline 23 & Yessica Febriani WP & 75 & 75 & 75 & 75.0 \\
\hline 24 & Yonatan Febriyan H & 75 & 75 & 75 & 75.0 \\
\hline 25 & Yusuf Setyanto FM & 75 & 75 & 75 & 75.0 \\
\hline 26 & Dafa Putra Nadhiar & 50 & 75 & 50 & 58.3 \\
\hline 27 & Fachrum Fairus NH & 50 & 75 & 50 & 58.3 \\
\hline 28 & Dewi Nuhnialika P. & 25 & 25 & 25 & 25.0 \\
\hline 29 & Alissa Novita Sari & 75 & 100 & 75 & 83.3 \\
\hline 30 & Bima Nurdiansyah & 50 & 75 & 50 & 58.3 \\
\hline \multirow[t]{2}{*}{31} & Angga Perdana & 50 & 50 & 50 & 50 \\
\hline & Jumlah Rata-Rata & 63,74 & 64,58 & $\mathbf{5 9 , 7 7}$ & 62,69 \\
\hline
\end{tabular}

Keterangan aspek yang diamati:

1. Keterampilan berbagi, meliputi keterampilan keterampilan menggunakan kesepakatan, menghargai kontribusi orang lain, dan keterampilan bertanya;

2. Keterampilan partisipasi, meliputi selalu berada dalam kelompok, menghormati perbedaan pendapat, dan mendengar dengan aktif;

3. Keterampilan komunikasi, meliputi mengungkapkan ketidaksetujuan dengan cara yang sopan, mengulang informasi dengan kalimat sendiri, dan memeriksa kebenaran informasi yang diterima.

Keterangan nilai:

- Skor $4 /$ nilai $100=$ jika tiap aspek keterampilan sosial menunjukkan 3 keterampilan

- Skor 3/nilai $75=$ jika tiap aspek keterampilan sosial menunjukkan 2 keterampilan

- Skor $2 /$ nilai $50=$ jika tiap aspek keterampilan sosial menunjukkan 1 keterampilan 
- Skor $1 /$ nilai $25=$ jika tidak menunjukkan sikap keterampilan sosial

Tabel 2 Hasil Observasi Penilaian Keterampilan Sosial Siswa Siklus II

\begin{tabular}{|c|c|c|c|c|c|}
\hline \multirow[t]{2}{*}{ No. } & \multirow[t]{2}{*}{ Nama Siswa } & \multicolumn{3}{|c|}{$\begin{array}{c}\text { Nilai tiap aspek yang } \\
\text { diamati }\end{array}$} & \multirow{2}{*}{$\begin{array}{c}\text { Rata-Rata } \\
\text { Nilai }\end{array}$} \\
\hline & & 1 & 2 & 3 & \\
\hline 1 & Armando Ricantona & 100 & 100 & 100 & 100 \\
\hline 2 & Arga Anggar & 75 & 75 & 100 & 83.3 \\
\hline 3 & Ayu Kumalasari & 75 & 100 & 75 & 83.3 \\
\hline 4 & Ade Irma Surya & 75 & 75 & 75 & 75 \\
\hline 5 & Arung Ega $\mathrm{R}$ & 75 & 75 & 75 & 75 \\
\hline 6 & Dimas Firmansyah & 100 & 100 & 100 & 100 \\
\hline 7 & Devi Yunita Sari & 100 & 100 & 100 & 100 \\
\hline 8 & Ester Danisa & 100 & 100 & 100 & 100 \\
\hline 9 & Ferian Dandi A.S & 100 & 100 & 75 & 91.7 \\
\hline 10 & Hawa Mayra JK & 100 & 100 & 100 & 100 \\
\hline 11 & Hifni Khoirul Rosyid & 75 & 75 & 75 & 75 \\
\hline 12 & Ibnu Setiawan & 100 & 75 & 75 & 83.3 \\
\hline 13 & Ika Puji Lestari & 75 & 75 & 75 & 75 \\
\hline 14 & Iriana Wahyuning & 75 & 75 & 75 & 75 \\
\hline 15 & Irvan Putra M & 75 & 75 & 75 & 75 \\
\hline 16 & Lucya Nurani DP & 100 & 75 & 100 & 91.7 \\
\hline 17 & Mario Suryoko & 75 & 75 & 75 & 75 \\
\hline 18 & Novi Nurhandayani & 100 & 100 & 75 & 91.7 \\
\hline 19 & Putri lioni M & 75 & 100 & 100 & 91.7 \\
\hline 20 & Rizal Afridi & 75 & 75 & 75 & 75 \\
\hline 21 & Rukmania Nur A & 75 & 75 & 75 & 75 \\
\hline 22 & Tania Putri P & 100 & 100 & 100 & 100 \\
\hline 23 & Yessica Febriani WP & 100 & 100 & 100 & 100 \\
\hline 24 & Yonatan Febriyan H & 100 & 100 & 100 & 100 \\
\hline 25 & Yusuf Setyanto FM & 100 & 100 & 100 & 100 \\
\hline 26 & Dafa Putra Nadhiar & 75 & 75 & 75 & 75 \\
\hline 27 & Fachrum Fairus NH & 75 & 100 & 75 & 83.3 \\
\hline 28 & Dewi Nuhnialika P. & 50 & 50 & 50 & 50 \\
\hline 29 & Alissa Novita Sari & 75 & 100 & 100 & 91.7 \\
\hline 30 & Bima Nurdiansyah & 75 & 100 & 75 & 83.3 \\
\hline \multirow[t]{2}{*}{31} & Angga Perdana & 75 & 75 & 75 & 75 \\
\hline & Jumlah Rata-Rata & 84,67 & 87,09 & 84,67 & 85,48 \\
\hline
\end{tabular}

Hasil penelitian untuk melatihkan keterampilan sosial siswa yang dilakukan pada siklus 1 , menunjukkan bahwa umumnya siswa agak kurang dalam melakukan keterampilan komunikasi, keterampilan berbagi dan keterampilan partisipasi. Hal tersebut dapat dilihat pada tabel 1, dimana nilai keterampilan sosial siswa rata-rata 62,69 , yang artinya rata-rata setiap siswa hanya menunjukkan 1 macam keterampilan sosial pada setiap aspeknya. Hasil refleksi di siklus I dapat diketahui bahwa siswa masih kurang dalam hal menunjukkan keterampilan sosialnya. Hal ini kemudian menjadi perhatian peneliti untuk diperbaiki pada siklus berikutnya, dimana pada siklus kedua, guru lebih menekankan pada pentingnya seseorang untuk mampu berbagi dengan orang lain, 
berpartisipasi dalam setiap kegiatan, dan mengkomunikasikan ide-ide kreatifnya. Hal tersebut ditekankan untuk menunjang proses belajarnya sehingga siswa dapat berprestasi baik di sekolahnya.

Hasil penelitian pada siklus kedua, ketiga aspek keterampilan sosial mulai menunjukkan adanya peningkatan, dimana siswa dapat melakukan komunikasi, berbagi dan berpartisipasi yang lebih baik lagi dengan temannya dalam diskusi. Hal tersebut dapat dilihat pada tabel 2, dimana nilai keterampilan sosial siswa rata-rata 85,48, yang artinya rata-rata setiap siswa sudah menunjukkan 2 sampai 3 macam keterampilan sosial pada setiap aspeknya. Peningkatan setiap aspeknya dari siklus I ke siklus II dapat dilihat pada tabel berikut.

Tabel 3 Peningkatan Aspek Keterampilan Sosial dari Siklus I ke Siklus II

\begin{tabular}{clccc} 
No & $\begin{array}{c}\text { Aspek Keterampilan } \\
\text { Sosial }\end{array}$ & $\begin{array}{c}\text { Nilai Rata- } \\
\text { Rata Siklus I }\end{array}$ & $\begin{array}{c}\text { Nilai Rata- } \\
\text { Rata Siklus II }\end{array}$ & $\begin{array}{c}\text { Jumlah } \\
\text { Peningkatan }\end{array}$ \\
\hline 1. & Berbagi & 63,74 & 84,67 & 20,93 \\
2. & Partisipasi & 64,58 & 87,09 & 22,51 \\
3. & Komunikasi & 59,77 & 84,67 & 24,90 \\
\hline & Jumlah Rata-Rata & $\mathbf{6 2 , 6 9}$ & $\mathbf{8 5 , 4 8}$ & $\mathbf{2 2 , 7 8}$ \\
\hline
\end{tabular}

Dari Tabel 3 di atas dapat dilihat bahwa terjadi peningkatan setiap aspek keterampilan sosial diantaranya, keterampilan berbagi dari Siklus I rata-rata 63,74 ke Siklus II rata-rata 84,67 keterampilan partisipasi dari Siklus I rata-rata 64,58 ke Siklus II rata-rata 87,09; dan keterampilan komunikasi dari Siklus I rata-rata 59,77 ke Siklus II rata-rata 84,67 . Jumlah peningkatan rata-rata keterampilan sosial sebesar 22,78. Thalib (2010:163) menyatakan seorang siswa dikatakan mampu berketerampilan sosial tatkala ia dapat berkomunikasi dengan baik sesuai aturan (tatacara) dengan sesamanya di dalam sebuah kelompok, mau menerima atau menghargai pendapat teman yang berbeda, dan mampu berpartisipasi dengan anggota kelompok lain. Secara umum, proses latihan berbagai keterampilan sosial dapat berlangsung dengan baik sebagai akibat dari penerapan model pembelajaran kooperatif itu sendiri. Hal ini sejalan dengan pandangan Smith dan MacGregor (1992) bahwa pembelajaran kooperatif menanamkan kepada siswa tujuan akademik dan tujuan keterampilan sosial. Jadi melalui pembelajaran kooperatif dapat dicapai dua manfaat sekaligus yang saling menunjang yakni terjadinya peningkatan kemampuan akademis, sekaligus siswa akan terlatih untuk menerapkan berbagai keterampilan sosial dalam berhubungan dengan orang lain.

\section{E. PENUTUP}

Berdasarkan hasil penelitian dan analisis data yang telah dilakukan disimpulkan bahwa melalui penerapan pembelajaran kooperatif tipe TSOS dapat meningkatkan keterampilan sosial siswa kelas IV pada mata pelajaran IPA di SDN Kanigoro 3 Madiun yang ditunjukkan dengan data peningkatan, yaitu: keterampilan berbagi dari Siklus I rata-rata 63,74 ke Siklus II rata-rata 84,67; keterampilan partisipasi dari Siklus I rata-rata 64,58 ke Siklus II rata-rata 87,09; dan keterampilan komunikasi dari Siklus I rata-rata 59,77 ke Siklus II rata-rata 84,67 . 


\section{DAFTAR RUJUKAN}

Arends, R. I. 1997. Classroom Instruction and Management. New York: McGraw Hill.

Ghony, D. 2008. Penelitian Tindakan Kelas. Malang: UIN-Malang Press.

Arikunto, S. 2009. Dasar-Dasar Evaluasi Pendidikan. Jakarta: Bumi Aksara.

Kagan, S. 2009. Teach less, Learn More (Online). (http://www.kaganonline.com, diakses 24 Februari 2011).

Maitland, L., Bookman, B., Valenti, J., dan Latourelle, S., 2001. Two Stay One Stray (Online). (http://www.flcc.edu/biochem/toolbox/22TwoStayOne Stray.doc, diakses 5 Maret 2011).

Miller, C.K., dan Peterson, R.L., 1992. Cooperative Learning (Online). (http://www.Indiana.edu/ safeschl, diakses 15 Februari 2011).

Millis, B.J. 2009. Cooperative Learning Structures (Online). (http://www.utexas.edu/academic/diia/research/projects/hewlett/cooperativ e.php, diakses 2 Maret 2011).

Santrock, J.W. 2007. Psikologi Pendidikan. Jakarta: Kencana.

Slavin, R.E. 1995. Cooperative Learning, Theory, Research, and Practice. Boston: Allyn and Bacon.

Smith, B.L., dan McGregor, J.T. 1992. What is Collaborative Learning? (Online). (http://www.learningcommons.evergreen.edu/pdf/collab.pdf, diakses 17 Februari 2011). 